\title{
Market Discipline in Post- Transformation Era: A Study on Banking Sector
}

\author{
Dr. Sathya Swaroop Debasish \\ P.G. Department of Business Management \\ Fakir Mohan University, Vyasa Vihar, Balasore-19, Orissa, India \\ E-mail: sathyaswaroop2000@yahoo.com \\ Dr. Bhagaban Das (Corresponding Author) \\ P.G. Department of Business Management \\ Fakir Mohan University, Vyasa Vihar, Balasore-19, Orissa, India \\ E-mail: bhagaban_fm@yahoo.co.in
}

\begin{abstract}
This paper attempts to investigate the existence of Market Discipline in the Indian commercial banks over the period 2001-2008 i.e., 7 years. This period is characterized by second round of banking sector reform as suggested by Narsimham Committee for banking restructuring and market discipline. A total of 63 scheduled commercial banks were taken as the sample size which included 27 public sector banks, 23 private banks and 13 foreign banks. Two dependent variables viz. total deposits held by banks and interest paid on deposits to total deposit ratio are considered in this study. We hypothesize that the dependent variables in this study, which signifies the existence or otherwise of market discipline depends on three sets of variables: a) bank-specific; b) banking industry level; and c) macroeconomic. The findings show that while bank-specific factors, and in particular, policy variables, in addition to bank-specific indicators tend to be dominant in case of private banks. For foreign banks, the macroeconomic conditions tend to overwhelm bank-specific factors in explaining behavior of depositors. This provides testimony of market discipline in the banking sector in India.
\end{abstract}

Keywords: Banking, Macroeconomic, Market Discipline, Regression

\section{Introduction}

Over the last few decades, both developed and developing economies have witnessed a spate of financial crisis spearheaded by failure in the banking system. The costs of such crises have often been large, ranging from a modest 3 per cent of GDP for the US Saving \& Loans crisis in early 1980's to around 35 per cent of GDP for Thailand and a much higher 55 per cent of GDP for Indonesia during the period 1997-99 (Caprio and Klingebiel, 2003). A typical way to address the issue is to tighten prudential supervision (Mishkin, 2001). Alternately, rather than depending on regulatory action alone, banking authorities can supplement the same by increasing their reliance on market discipline to reinforce oversight of banks. The potential benefits of market discipline could be particularly important in developing economies. This is primarily because financial systems in these economies tend to be predominantly bank-based. Accordingly, in view of the overwhelming dominance of banks, it is widely believed that a well-functioning banking system can play a significant role in efficient allocation of savings. However, in view of the growing complexity of banking organizations, traditional procedures of supervision can, at best, have limited appeal. As a consequence, considerable interest has been generated in recent times in harnessing market forces to assist regulatory goals.

Market discipline is a process by which investors (bondholders/ depositors) assess changes in bank risk and take actions leading to the adoption of those measures needed to control the institution's level of risk. The idea of leveraging market discipline to supplement supervisory efforts and corporate governance practices is by no means new. Market discipline in the banking sector can be described as 'private counterparty supervision' (Greenspan, 2001). Such discipline usually takes one of two forms: direct discipline and indirect discipline (Federal Reserve, 2000). Direct market discipline is the pressure applied by investors on banks through the interest rate paid (e.g., through sub-ordinated debt), which, in turn, reflects each bank's risk profile. The higher the risk profile, the higher would be the interest rate paid. Indirect market discipline, on the other hand, is the pressure applied by regulators on the basis of sub-ordinated debt prices in the secondary market. To the extent that such prices reflect the (absolute or relative) probability of loss by issuing banks, they can provide valuable input into decisions by supervisors and counter-parties affecting the bank.

There are a number of potential benefits from enhancing market discipline in a country's banking sector. First, by punishing excessive risk-taking by banks, increased market discipline may reduce moral hazard incentives. Second, market discipline may improve the efficiency of banks by pressurizing some of the relatively inefficient banks to become more efficient or to exit the industry (Berger, 1991). Third, evidence indicates that markets give signals about 
the credit standings of financial firms, which, combined with inside information gained by supervisory procedures, can increase the efficacy of the overall supervisory process. Finally, market discipline might be able to supplement traditional supervisory assessments to distinguish 'good' banks from 'bad' ones and therefore, lower overall social costs of bank supervision (Flannery, 2001).

The present study focuses on Indian banking sector as a case study. In the last decade, India has undergone widespread liberalisation of the banking sector with the avowed objective of 'enhancing efficiency, productivity and profitability' (RBI, 1991). It seems appropriate to conduct a study of market discipline for India, since it has made significant efforts to promote the role of market forces in regulating banks. Banks are presently required to disclose, among others, not only their capital adequacy (tier I and tier II, separately) ratios, net NPA to net advances, return on assets and government holdings, but also the amount of sub-ordinated debt raised as tier II capital, movements in NPAs, maturity pattern of deposits and borrowings and lending to sensitive sectors. Towards this end, we estimate reduced-form equations of individual bank deposits/interest paid on deposits as functions of bank fundamentals, banking industry-level and macroeconomic variables.

The remainder of the paper is structured as follows: Section I presents an overview of the literature on market discipline, Section II describes the empirical methodology used in the study, Section III provides a description of the data, Section IV presents and discusses the empirical results and finally, the concluding remarks are gathered in Section V.

\section{Literature Review}

Market discipline is however, not an issue for developed countries alone. Nakaso et al. (2000), for instance, argue that market discipline did not operate efficiently in Japan due largely to insufficient financial infrastructure (weak accountancy rules, inadequate disclosure standards, etc). Even for the U.S., where market discipline is arguably the strongest, evidence suggests that neither supervisors, rating agencies nor equity investors are unambiguously more timely and accurate in their assessment of risk than others. All three groups produce valuable complementary information that contributes towards improving the performance of large banks (Berger et al., 2000).

The majority of the existing studies on market discipline pertain to the US commercial banking industry over the last two decades. Baer and Brewer (1986), Ellis and Flannery (1992), Flannery and Sorescu (1996), Jagtiani and Lemieux (2000) and Sironi (2000) employ yield spreads (the difference between the market yield on bank debt and a risk-free asset like Government paper) as an indicator of the market's perception of bank risk. These studies support the hypothesis that yields on uninsured deposits contain risk premia. This, in effect, implies that uninsured depositors charge higher interest rates to riskier banks.Birchler and Maechler (2001), examining market discipline in the Swiss banking sector, find that depositors are sensitive to bank-specific fundamentals and to institutional changes in the Swiss depositor protection system. Finally, Martinez Peria and Schmukler (2001) observe for Argentina, Chile and Mexico, that even small, insured depositors exert market discipline by withdrawing deposits from weak banks. Park and Peristiani, 1998; Calomiris and Powell, 2001) examine market discipline by looking at the effect of depository's institution risk on both the pricing and growth of uninsured deposits. Overall, these studies find that riskier banks pay higher interest rates, but, at the same time, attract smaller amounts of uninsured deposits. A recent study addresses this topic by examining the existence of market discipline in the Indian banking sector (Ghosh and Das, 2003). In particular, the study considers two specific aspects of market discipline, viz., (a) do bank fundamentals influence depositor willingness to entrust deposits at a particular bank? and, (b) do differences among bank groups affect the degree of market discipline in the banking sector?

\section{Research Methodology}

We hypothesize that the dependent variable in the study, which signifies the existence or otherwise of market discipline depends on three sets of variables: (a) bank-specific; (b) banking industry-level; and, (c) macroeconomic. Towards this end, we estimate the following reduced form equation for the dependent variable:

$\mathrm{Y}_{\mathrm{i}, \mathrm{t}}=\mathrm{a}+\mathrm{b} \mathrm{S}_{\mathrm{t}}+\mathrm{e} \mathrm{M}_{\mathrm{t}}+\mathrm{dB}_{\mathrm{i}, \mathrm{t}-1} \quad$ (1)

In equation (1), $\mathrm{Y}_{\mathrm{i}, \mathrm{t}}$ represents the individual bank-specific dependent variable, $\mathrm{T}$ is the number of observations per bank, $\mathrm{S}_{\mathrm{t}}$ stands for the systemic (or bank industry specific) variable for year $\mathrm{t}$, while $\mathrm{M}_{\mathrm{t}}$ is a vector of macroeconomic variable for year $\mathrm{t}$. Both the systemic and macroeconomic variables change over time, but not across banks. $\mathrm{B}_{\mathrm{i}, \mathrm{t}-\mathrm{l}}$ is a vector of bank specific variables. $\mu_{\mathrm{i}}$ is the bank-specific or fixed effect. Thus, according to equation (1), the dependent variable is determined by three major factors: the behaviour of deposits in the overall banking system, the developments in the macro-economy and the evolution of bank-risk characteristics.

The question arises as regards the choice of dependent variable. Depositors can exercise market discipline on banks through two channels: by requiring higher interest rates (price variable) and/or by withdrawing their deposits from riskier banks (quantity variable). The approach adopted in the present paper focuses on both the quantity and price approaches. In case of the quantity approach, $\mathrm{Y}_{\mathrm{i}, \mathrm{t}}$ represents the first difference of the log of total deposits held by bank $i$ at time t. In case of the price approach, the only calculable interest rate is an implicit rate, rather than a market rate. This implicit rate is calculated as the interest paid on deposits to total deposits. 


\subsection{Bank Specific Variables}

The vector $\mathrm{B}_{\mathrm{i}, \mathrm{t}-1}$ contains several banks-specific fundamentals which are intended to measure bank's risk exposure. The variables are derived from the CAMEL rating system of banks (where the acronym CAMEL stands for Capital adequacy, Asset quality, Management, Earnings and Liquidity).

a) Capital Adequacy: Capital adequacy is measured by the ratio of capital to risk-weighted assets (CRAR). We expect the capital adequacy variable to exert a positive influence on bank deposits and a lower interest outgo.

b) Asset Quality: We employ the gross non-performing loans to gross advances ratio (GNPA), which is more indicative of the quality of credit decisions made by bankers. As higher GNPA is indicative of poor credit decision-making, we expect this variable to have a negative influence on deposits and an adverse outcome in terms of higher interest rates.

c) Management: To account for management quality, we include the ratio of non-interest expenditures to total assets (NIE). We expect this variable to have a negative relationship with deposits and a positive linkage with the interest rate variable.

d) Earnings: We measure bank earnings with the ratio of spread (net interest income) to total assets. We expect this variable to have a positive effect on deposits and an inverse relation with interest rate.

e) Liquidity: The cash plus balances with central bank to total asset ratio (LQD) is included as an indicator of bank liquidity. Banks with a larger volume of liquid assets are perceived to be safer. This would imply a positive relation between deposits and liquidity and a negative movement between liquidity and interest rate.

\subsection{Bank-industry Specific Variables}

In order to control for the behavior of the overall banking sector, our estimations include the following variables:

a) The ratio of cash outside banks to system deposits (CASH).

b) Capital Adequacy Ratio.

c) Prime Lending Rate (PLR)

\subsection{Macroeconomic Variables}

Deposits at individual banks or the price paid on deposits can also be influenced by the state of the overall economy and thus, we control for the impact of macroeconomic variables. In particular, we evaluate the effect of the following factors:

a) Growth rate of real gross domestic product (GDPR)

b) Wholesale price index (WPI), and

c) Growth rate of Money Supply (M3)

As these variables reflect the relative strength of the economy, we expect each having a positive relationship with the quantity variable and a negative relation with the price variable. In order to ascertain the joint significance of the bank-specific variables, we report the corresponding Statistics. Similar F-statistics are also report for the joint significance of macro and system variables are also reported.

\section{Data Sources}

Three types of data are used in this study viz. bank-specific, systemic and macroeconomic variable. The bank-specific data used in the study have been obtained from the Report on Trend and Progress of Banking in India and Statistical Tables Relating to Banks in India. Macroeconomic and systemic data come both form the Handbook of Statistics on Indian Economy as well as from the International Financial Statistics of the IMF. Bank-specific data are on an annual basis. Our analysis for the said variable pertains to the period 2001-2008 i.e. 7 years. 63 scheduled commercial banks were taken as the samples size which includes 27 public sector banks, 23 private banks and 13 foreign banks. (See Appendix-1).

\section{Analysis and Findings}

This section evaluates whether there is evidence of market discipline, in other words, whether depositors respond to bank risk-taking by withdrawing deposits and/or by requiring higher interest rates on deposits. Table 1 presents the results for the commercial banking sector as a whole. The results lend credence to the finding that deposits respond to bank risk taking. Among the bank-specific factors, a rise in the CRAR fosters deposit growth. Secondly, banks with relatively more liquid assets experience a fall in their deposit base, probably mirroring the fact of holding low yielding short-term assets as reflective of poor cash management. The coefficient on the CASH variable is positive and significant; indicating to the fact that deposits with the entire banking system grew at a slower rate than cash outside banks. The rapid growth of cash outside banks might be a consequence of increase in system-wide liquidity in the face of declining interest rates on bank deposits and limited alternative avenues for parking of funds by depositors.

Insert Table 1 Here

Finally, at the macroeconomic level, higher growth in GDP translates into higher growth in deposits and the impact is found to be statistically significant. Finally, deposit growth in positively related to inflation as proxied by CPI, suggesting that higher uncertainty propels depositors to lower their cash holdings and instead, keep their money in deposits. The F-test reveals that bank specific factors are jointly significant at 1 per cent and 5 per cent level. 
The results lend credence to the finding that deposits respond to bank risk taking. Among the bank-specific factors, a rise in the CRAR fosters deposit growth. Secondly, banks with relatively more liquid assets experience a fall in their deposit base, probably mirroring the fact of holding low yielding short-term assets as reflective of poor cash management. The coefficient on the CASH variable is positive and significant; indicating to the fact that deposits with the entire banking system grew at a slower rate than cash outside banks. The rapid growth of cash outside banks might be a consequence of increase in system-wide liquidity in the face of declining interest rates on bank deposits and limited alternative avenues for parking of funds by depositors. Finally, at the macroeconomic level, higher growth in GDP translates into higher growth in deposits and the impact is found to be statistically significant. Finally, deposit growth in positively related to inflation as proxied by CPI, suggesting that higher uncertainty propels depositors to lower their cash holdings and instead, keep their money in deposits. The F-test reveals that bank specific factors are jointly significant at 1 per cent and 5 per cent level.

The results pertaining to the interest rate variable (Table-1, last Column) also paint a similar story. Banks with higher non-performing loans and lower earnings pay higher interest rates. Thus, banks with poor asset quality and limited earning capacity end up paying higher implicit price. Also, banks with lower liquidity pay higher interest rates on deposits, confirming to the fact that liquidity profile of banks acts as a crucial indicator of market discipline. The table also shows that bank risk characteristics are jointly significant in the price equation, even after controlling for fixed effects and time effects. This lends further support to the existence of market discipline in the banking sector in India.

The next obvious question which arises is: which factors tend to be more dominant for certain bank groups vis-à-vis others? The answer to this question is exhibited in Tables 2 and 3. Table 2 depicts the results for bank groups for the quantity (deposit growth rate) variable, whereas the results pertaining to the price variable (interest paid on deposits) is provided in Table 3.

Insert Table 2 Here

As Table 2 reveals, for the public sector bank-group, high capital ratio is associated with significantly higher deposit growth, lending credence to this risk-weighted variable in explaining depositor behaviour. Among others, poor asset quality and inefficient management practices tends to lower deposit growth in the concerned bank, while excessive liquidity also tends to exert a negative effect on deposit growth. At the bank-industry specific level, the coefficient on $\mathrm{CASH}$ is positive and significant; hinting at the possibility that greater liquidity in the system provides depositors a sense of comfort regarding the safety of their deposits, so much so that bank deposits actually rise, rather than fall, as a result. It is pertinent to mention here that examining market discipline in the Latin American economies of Argentina, Chile and Mexico, Martinez Peria and Schmukler (2001) observed that while there was evidence to support the existence of contagion effect in the Argentine and Chilean banking system, it was conspicuous by its absence in the Mexican banking industry. Finally, higher GDP growth tends to exert a positive influence on deposit growth, concluding that the macroeconomic environment has significant effect in explaining depositor behaviour in public sector banks. The F-statistics for bank fundamentals are jointly significant, attesting to the existence of market discipline among depositors of public sector banks.

The results are, however, distinctly different in the case of private and foreign banks. For private banks in particular, deposit growth is mostly driven positively by capitalization and negatively by non-performing assets to the exclusion of other bank-specific variables. More importantly however, systemic and macroeconomic variables play a crucial role in determining deposit growth among private banks. In particular, deposit growth responds positively to POLICY, hinting at the possibility that depositors with private banks responds pro-actively to a policy announcement. Finally, as in the case with public sector banks, deposit growth is driven positively by GDP growth. The results for foreign banks, on the other hand, seem to demonstrate that neither of asset quality, capital ratio or earnings plays an influential role in harnessing deposit growth. Only liquidity plays an important role in influencing deposits, hinting at the possibility that depositors take limited cognizance of the overall soundness of foreign banks in entrusting their deposits. At the bank-industry level, there is evidence to suggest the presence of contagion among the foreign bank group as evidenced by the negative and significant coefficient on CASH.

The results pertaining to the interest rate variable on various banking sectors is presented in Table 3 . The lower the quantum of sticky loans, the greater is the compensation required for depositors. In particular, this impact is significant for public sector and foreign banks. Bank capitalisation plays a crucial role in determining the interest rate paid by private banks: lower the capital levels, larger the interest outgo. Interest rate paid by public and private banks are driven by non-interest expenses in the sense that lower non-interest expenditures tend to be associated with higher interest outgo. Lower non-interest expenses imply lower overhead costs (wage bill, printing and advertisement cost, etc). This, in effect, adversely affects customer sentiment regarding the service provided by the bank, so that the bank has to perforce pay higher interest rates to attract customers. Earnings are important in explaining interest paid by foreign banks. For public sector and foreign banks, size is inversely associated with interest rates, probably reflecting the public perception that larger banks have lower probability of failure and can afford to pay lower interest rates. Among bank-industry variables, there is limited evidence to support contagion effect among public sector banks.

Insert Table 3 Here 
The macroeconomic variables play an important role in determining interest paid by public sector and private banks: expectedly, lower GDP growth is associated with higher interest rates. A volatile economic environment is associated with lower interest paid, reflecting consumer preferences to park their funds in bank deposits, irrespective of interest paid, in the face of uncertainties. The F-tests show that the bank-specific variables are jointly significant at conventional levels of significance. This, in effect, supports the presence of market discipline in the banking sector in India.

\section{Conclusion}

The purpose of the paper has been to examine the existence of market discipline in the banking sector in India during the period 2001-08. This period is characterized by second round of banking sector reform as suggested by Narasimham Committee for banking restructuring and market discipline. Towards this end, we employed bank level data to estimate reduced form equations, in which the dependent variable (quantity, as proxied by time deposits; price, as proxied by implicit interest rate) is modeled as function of bank-specific, systemic and macroeconomic variables. Our results enabled us to conclude that depositors in India punish banks for risky behaviour. The tests for the joint significance of bank fundamentals were consistently rejected across equations. Put differently, we were unable to reject the null hypothesis that the bank risk variables were not relevant in explaining the behaviour of bank deposits or the interest rate paid on such deposits. This provides testimony towards the existence of market discipline in the banking sector in India. Summing up the foregoing discussion, while bank-specific factors are dominant in case of public sector banks, systemic factors, and in particular, policy variable, in addition to bank-specific indicators tend to be dominant in case of private banks. For foreign banks, the macroeconomic condition tends to overwhelm bank-specific factors in explaining behaviour of depositors. Nonetheless, the capital ratio is a key determinant of depositor behaviour for Indian banks, in general. Irrespective of the ownership pattern, liquidity plays a significant role in fostering deposit growth. In case of state-owned banks, bigger size of banks does not translate into higher deposit growth, suggesting that depositors are insensitive to the 'too-big-to-fail' effect. For private and foreign banks, there exists evidence of contagion effects influencing the deposit accretion process. Therefore, we can conclude that there exists market discipline in the Indian banking system. Despite its potential advantages, market discipline can only complement, not substitute supervision, because the stake of the Government and the market participants in the financial system are not perfectly aligned.

\section{References}

Baer, H and E.Brewer (1986). Uninsured Deposit as a Source of Market Discipline. Economic Perspectives: Federal Reserve Bank of Chicago.

Barajas, A and R.Steiner. (2000). Depositor Behaviour and Market Discipline in Colombia. IMF Working Paper, No.214, IMF: Washington, DC.

Berger, A.N. (1991). Market Discipline in Banking. Proceedings of a Conference on Bank Structure and Competition. Federal Reserve Bank of Chicago.

Birchler, U.W and A.M.Maechler. (2001). Do Depositors' Discipline Swiss Banks?. Discussion Paper, No.6, Swiss National Bank.

Calomiris, C and A.Powell. (2001). Can Emerging Market Bank Regulators Establish Credible Discipline? The Case of Argentina, 1992-99'. in F.S.Mishkin (ed.) Prudential Supervision: What Works and What Doesn't'?. University of Chicago Press: USA.

Ghosh, S. and A.Das. (2003). Market Discipline in the Indian Banking Sector: An Empirical Exploration. NSE Research Initiative. NSE: Mumbai.

Ellis, D and M.Flannery. (1992). Does the Debt Market Assess Large Banks' Risk? Time Series Evidence from Money Center CDS'. Journal of Monetary Economics. 30, pp.481-502.

Flannery, M. (1998). Using Market Information in Prudential Bank Supervision: A Review of U.S. Empirical Evidence. Journal of Money, Credit and Banking. 3, pp.273-305.

Flannery, M. (2001). Two Faces of Market Discipline. Journal of Financial Services Research. 20, p.107- 119.

Flannery, M and S.M.Soresc. (1996). Evidence of Bank Market Discipline in Sub-ordinated Debt Yields. Journal of Finance. 4, pp.1347-1375.

Greenspan, A. (2001). Harnessing Market Discipline. The Region: Federal Reserve Bank of Minneapolis.

Jagtiani, J and C.Lemieux. (2001). Market Discipline Prior to Bank Failure. Journal of Economics and Business. 53, pp.313-324.

Martinez Peria, M.S. and S.Schmukler. (2001). Do Depositors Punish Banks for Bad Behaviour: Market Discipline, Deposit Insurance and Banking Crises. Journal of Finance. 56, pp.1029-1051.

Park, S and S.Peristiani. (1998). Market Discipline by Thrift Depositors. Journal of Money, Credit and Banking. 30, pp.347-364.

Reserve Bank of India. (1991). Report of the Committee on the Financial Systems (Chairman: Shri M.Narasimham). RBI: Mumbai.

Reserve Bank of India. Report on Trend and Progress of Banking in India (various years). RBI: Mumbai. 
Reserve Bank of India. Statistical Tables Relating to Banks in India (various years). RBI: Mumbai.

Sironi, A. (2000). Testing for Market Discipline in the European Banking Industry: Evidence from Sub-ordinated Debt Issues. International Finance Discussion Paper No. 40. Federal Reserve Board.

\begin{tabular}{|c|c|c|c|c|c|}
\hline \multicolumn{2}{|c|}{ I. Public Sector Bank } & \multicolumn{2}{|c|}{ II. Private Sector Banks } & \multicolumn{2}{|c|}{ III Foreign Banks } \\
\hline 1. & Allahabad Bank & & Bharat Overseas Bank Ltd. & & ABN-Amero Bank N.V. \\
\hline 2. & Andhra Bank & 29. & Development Credit Bank Ltd. & 52. & Bank Muscat SAOG \\
\hline 3. & Bank of Baroda & 30. & Lord Krishna Bank Ltd. & 53. & Ban of America NA \\
\hline 4. & Bank of India & 31. & Tamiland Mercantile Bank Ltd. & 54. & Bank of Ceylon \\
\hline 5. & Bank of Maharashtra & 32. & The Bank of Rajasthan Ltd. & 55. & BNP Paribas \\
\hline 6. & Canara Bank & 33. & The Catholic Syrian Bank Ltd. & 56. & Chinatrust Commercial Bank \\
\hline 7. & Central Bank of India & 34. & The Dhanalakhsmi Bank Ltd. & 57. & Citibank N.A. \\
\hline 8. & Corporation Bank & 35. & The Federal Bank Ltd. & 58. & Commerzbank AG \\
\hline 9. & Dena Bank & 36. & The Jammu \& Kashmir Bank Ltd. & 59. & Credit Lyonnais \\
\hline 10. & Indian Bank & 37. & The Karnataka Bank Ltd. & 60. & Deustsche Bank AG \\
\hline 11. & Indian Overseas Bank & 38. & The Karur Vysya Bank Ltd. & 61. & ING Bank \\
\hline 12. & Oriental Bank of Commerce & 39. & The Lakshmi Vilas Bank Ltd. & 62. & JP Morgan Chase Bank \\
\hline 13. & Punjab \& Sind Bank & 40. & The Nedungadi Bank Ltd. & 63. & Standard Chartered Bank \\
\hline 14. & Punjab National Bank & 41. & The South Indian Bank Ltd. & & \\
\hline 15. & Syndicate Bank & 42. & The United Western Bank Ltd. & & \\
\hline 16. & UCO Bank & 43. & Bank of Punjab Ltd. & & \\
\hline 17. & Union Bank of India & 44. & Centurian Bank Ltd. & & \\
\hline 18. & United Bank of India & 45. & Global Trust Bank Ltd. & & \\
\hline 19. & Vijaya Bank & 46. & HDFC Bank Ltd. & & \\
\hline 20. & State Bank of India & 47. & ICICI Bank Ltd. & & \\
\hline 21. & State Bank of Hyderabad & & IDBI Bank Ltd. & & \\
\hline 22. & State Bank of Indore & 49. & IndusInd Bank Ltd. & & \\
\hline 23. & State Bank of Mysore & 50. & UTI Bank Ltd. & & \\
\hline 24. & State Bank of Patiala & & & & \\
\hline 25. & State Bank of Saurashtra & & & & \\
\hline 26. & State Bank of Trancore & & & & \\
\hline 27. & State Bank of Bikaner \& Jaipur & & & & \\
\hline
\end{tabular}

Table 1. Regression Results of Total Deposits and Interest Paid On Deposits on Risk Characteristics of Indian Banking

\begin{tabular}{|l|l|l|}
\hline \multirow{2}{*}{ Independent Variables } & \multicolumn{2}{|l|}{ Dependent Variable } \\
\cline { 2 - 3 } I. Bank-Specific & Y = Total Deposits Coefficient & Y = Total Interest Rate Co-efficient \\
$\quad$ Intercept & $0.768(2.92)^{*}$ & \\
C Log (CRAR) & $0.519(3.17)^{*}$ & $7.258(2.25)^{* *}$ \\
A GNPA $\quad-0.012(-1.22)$ & $1.532(-1.27)$ \\
M NIE & $-0.872(2.40)^{* *}$ & $2.412(1.91)$ \\
E SPREAD & $2.470(3.42)^{*}$ & $-0.123(3.27)^{*}$ \\
L Log (LQD) & $-0.529(-2.07)^{* *}$ & $1.923(3.57)^{*}$ \\
II. Bank-Industry & & $-1.231(1.44)^{* *}$ \\
Log (CASH) & $0.791(2.59)^{*}$ & \\
CAR & $0.412(0.71)$ & $-2.018(2.01)^{* *}$ \\
PLR & $0.872(-1.22)$ & $-1.291(-1.17)$ \\
III. Macro-Economic & & $-0.923(-2.07) * *$ \\
GDP Growth & $0.351(-1.99)^{* *}$ & \\
Log (WPI) & $1.22(0.171)$ & $-1.770(1.22)$ \\
Money Supply Growth & $2.42(3.27)^{*}$ & $0.729(-1.03)$ \\
Adjusted R & 0.67 & $1.51(-2.02) * *$ \\
F-ratio & $3.92 *$ & 0.52 \\
\hline Number of Banks & 63 & $3.71 *$ \\
\hline
\end{tabular}

N.B.: Figures in parenthesis represent the t-values, ${ }^{*}$ and $* *$ indicate significance at 1 and 5 percent respectively. Log Transformation has been performed to obtain a normal distribution of the data under the variables CRAR, LQD, CASH and WPI. 
Table 2. Banking Group-Wise Analysis of Multiple Regression of Total Deposits to Bank Risk Characteristics

\begin{tabular}{|c|c|c|c|}
\hline \multirow{2}{*}{ Independent Variables } & \multicolumn{3}{|l|}{ Dependent Variable } \\
\hline & $\mathrm{Y}=$ Total Deposits Coefficient & $\mathrm{Y}=$ Total Interest Rate Coefficient & Foreign Banks \\
\hline \multicolumn{4}{|l|}{ Bank - Specific } \\
\hline Intercept & $0.619(2.57)^{* *}$ & $0.771(2.01)^{* *}$ & $1.212(-1.17)$ \\
\hline C $\quad \log (\mathrm{CRAR})$ & $0.014(2.11)^{* *}$ & $0.512(297) *$ & $0.017(-1.51)$ \\
\hline A GNPA & $-0.72(1.12)$ & $-0.005(-0.91)$ & $-0.008(-1.26)$ \\
\hline M NIE & $-0.173(-1.99)^{* *}$ & $-1.72(1.89)^{* *}$ & $0.071(0.79)$ \\
\hline E $\quad$ SPREAD & $1.271(-2.92) *$ & $1.92(-2.47) * *$ & $0.014(2.41)^{* *}$ \\
\hline $\mathrm{L} \quad \log (\mathrm{LQD})$ & $-0.331(1.22)$ & $0.077(0.52)$ & $-0.82(0.41)$ \\
\hline \multicolumn{4}{|l|}{ Bank-Industry } \\
\hline $\log (\mathrm{CASH})$ & $-1.72(2.19)^{* *}$ & $-0.921(3.16) *$ & $0.138(1.17)$ \\
\hline CAR & $-0.72(1.22)$ & $-0.081(-0.92)$ & $0.171(-0.81)$ \\
\hline PLR & $1.22(-2.49)^{* *}$ & $0.991(-2.19)^{* *}$ & $0.66(2.07)^{* *}$ \\
\hline \multicolumn{4}{|l|}{ Macro-Economic } \\
\hline GDP Growth & $0.517(-1.98)^{* *}$ & $0.021(0.42)$ & $0.117(-1.51)$ \\
\hline $\log (\mathrm{WPI})$ & $-0.88(-1.19)$ & $0.741(1.77)$ & $0.088 \quad(-1.42)$ \\
\hline Money Supply Growth & $1.721(2.79) *$ & $0.453(-2.99)$ & $0.924(2.11)^{* *}$ \\
\hline Adjusted R2 & 0.79 & 0.65 & 0.53 \\
\hline F-ratio & $4.51 *$ & 3.99 & $2.96 * *$ \\
\hline Number of Banks & 27 & 23 & 13 \\
\hline
\end{tabular}

Table 3. Banking Group-Wise Analysis of Multiple Regression of Interest Paid on Deposits to Bank Risk Characteristics

\begin{tabular}{|c|c|c|c|}
\hline \multirow[t]{2}{*}{ Independent Variables } & \multicolumn{3}{|l|}{ Dependent Variable } \\
\hline & $\mathrm{Y}=$ Total Deposits Coefficient & $\mathrm{Y}=$ Total Interest Rate Co-efficient & Foreign Banks \\
\hline \multicolumn{4}{|l|}{ Bank-Specific } \\
\hline Intercept & $8.11(2.18)^{* *}$ & $15.24(2.39)^{* *}$ & $9.97(1.98)^{* *}$ \\
\hline C $\quad \log (\mathrm{CRAR})$ & $0.172(2.59)^{*}$ & $-0.173(1.97)^{* *}$ & $0.249(-0.56)$ \\
\hline A GNPA & $0.017(-0.19)$ & $0.007(1.22)$ & $-0.074(1.61)$ \\
\hline M NIE & $-0.543(-1.34)$ & $-0.692(2.01)^{*}$ & $0.497(-0.01)$ \\
\hline E SPREAD & $1.412(2.79)^{*}$ & $0.992(3.40)^{*}$ & $0.073(-1.97)^{* *}$ \\
\hline L $\quad \log (\mathrm{LQD})$ & $-0.453(-1.22)$ & $-0.382(1.59)$ & $-0.227(-0.79)$ \\
\hline \multicolumn{4}{|l|}{ Bank-Industry } \\
\hline $\log (\mathrm{CASH})$ & $0.892(2.15)^{* *}$ & $0.711(2.41)^{* *}$ & $0.047(-1.26)$ \\
\hline CAR & $0.617(0.172)$ & $-0.522(0.87)$ & $0.281(-1.18)$ \\
\hline PLR & $0.183(2.17)^{* *}$ & $-0.745(3.41)^{*}$ & $-0.013(-1.78)$ \\
\hline \multicolumn{4}{|l|}{ Macro-Economic } \\
\hline GDP Growth & $0.612(-1.89)^{* *}$ & $0.007(0.012)$ & $0.221(-1.12)$ \\
\hline $\log (\mathrm{WPI})$ & $-0.73(1.24)$ & $1.123(1.41)$ & $0.093(-1.32)$ \\
\hline Money Supply Growth & $1.99(2.40)^{* *}$ & $0.337(2.66)$ & $1.19(2.18)^{* *}$ \\
\hline Adjusted $\mathrm{R}^{2}$ & 0.68 & 0.59 & 10.51 \\
\hline F-ratio & $3.77 *$ & $3.01 *$ & $2.72 * *$ \\
\hline Number of Banks & 27 & 23 & 13 \\
\hline
\end{tabular}

N.B: Figures in parenthesis devote the t-values, ${ }^{*}$ and $* *$ indicate significance at 1 and 5 percent respectively. Log Transformation has been performed to obtain a normal distribution of the data under the variables CRAR, LQD, CASH and WPI. 